\title{
PENGARUH UMP, PDRB DAN INVESTASI TERHADAP PENYERAPAN TENAGA KERJA INDUSTRI DI PULAU JAWA
}

\author{
${ }^{1}$ Desy Meilasari
}

\begin{abstract}
This research aims to analyze the effect of provincial Minimum wage (UMP), PDRB, and investment in the industrial sector of labor absorption on Java island in 2010-2016. Data used is a data panel consisting of data time series 2010 - 2016 and cross section six provinces namely DKI Jakarta, West Java, Central Java, IN Yogyakarta, East Java, and Banten. The Anaalisis tool used is a data regression panel i.e. Fixed Effect Model (FEM). The results showed that UMP has a significant effect on the labor absorption of the industrial sector on Java Island in 2010-2016. While the PDRB and investment have a positive and significant effect on the labor absorption of industrial sectors in Java Island in 2010-2016. Through this research, the government expects more cautious and creating a conducive investment climate so that the value of PDRB is increasing.
\end{abstract}

Keywords: Minimum Provincial Wages (UMP), GDRP, and Investment

\begin{abstract}
Abstrak
Penelitian ini bertujuan untuk menganalisis pengaruh Upah Minimum Provinsi (UMP), PDRB, dan investasi terhadap penyerapan tenaga kerja sektor industri di Pulau Jawa tahun 2010-2016. Data yang digunakan merupakan data panel yang terdiri dari data time series tahun 2010 - 2016 dan cross section enam Provinsi yaitu DKI Jakarta, Jawa Barat, Jawa Tengah, DI Yogyakarta, Jawa Timur, dan Banten. Alat anaalisis yang digunakan adalah regresi data panel yaitu Fixed Effect Model (FEM). Hasil penelitian menunjukkan bahwa UMP berpengaruh negatif dan signifikan terhadap penyerapan tenaga kerja sektor industri di Pulau Jawa tahun 2010-2016. Sedangkan PDRB dan investasi berpengaruh positif dan signifikan terhadap penyerapan tenaga kerja sektor industri di Pulau Jawa tahun 2010-2016. Melalui penelitian ini diharapkan pemerintah lebih berhati-hati dalam menentukan UMP, serta menciptakan iklim investasi yang kondusif sehingga nilai PDRB lebih meningkat.
\end{abstract}

Kata Kunci: Upah Minimum Provinsi (UMP), PDRB, dan Investasi

\section{Pendahuluan}

Penyerapan tenaga kerja merupakan salah satu faktor fundamental dalam mencerminkan kondisi perekonomian yang dinamis. Penyerapan tenaga kerja juga tidak lepas dari peranan pemerintah dalam penyusun kebijakan dalam meningkatkan tingkat kesejahteraan tenaga kerja. Pemerintah memiliki andil yang sangat kuat dalam menentukan kebijakan dalam mencapai pertumbuhan ekonomi yang tinggi. Penyerapan tenaga kerja atau biasa disebut sebagai pro-job menjadi agenda penting selain pro-poor (pengentasan kemiskinan, dan pro-growth (peningkatan pertumbuhan) (Kuncoro,2002:73). Penyerapan tenaga kerja dipengaruhi oleh berbagai faktor antara lain adalah pendapatan nasional, tingkat investasi, dan upah tenaga kerja. Perubahan pada faktor-faktor tersebut akan mempengaruhi tingkat penyerapan tenaga kerja. 
Menurut ekonom klasik seperti Adam Smith, David Ricardo dan Thomas Robert Malthus menyatakan bahwa selalu ada perlombaan antara tingkat perkembangan output dengan tingkat perkembangan penduduk yang akhirnya dimenangkan oleh perkembangan penduduk. Karena penduduk juga berfungsi sebagai tenaga kerja, maka akan terdapat kesulitan dalam penyediaan lapangan pekerjaan. Jika penduduk itu dapat memperoleh pekerjaan, maka hal ini akan dapat meningkatkan kesejahteraan bangsanya. Tetapi jika tidak memperoleh pekerjaan berarti mereka akan menganggur, dan justru akan menekan standar hidup bangsanya menjadi lebih rendah (Irawan dan Suparmoko, 2002).

Masalah ketenagakerjaan bukan hanya sekedar keterbatasan lapangan atau peluang kerja serta rendahnya produktivitas namun jauh lebih serius dengan penyebab yang berbeda-beda. Masalah pokok dalam ketenagakerjaan tertumpu pada kegagalan penciptaan lapangan kerja yang baru pada tingkat yang sebanding dengan laju pertumbuhan output industri. Seiring dengan berubahnya lingkungan makro ekonomi mayoritas negara-negara berkembang, angka pengangguran yang meningkat pesat terutama disebabkan oleh "terbatasnya permintaan" tenaga kerja, yang selanjutnya semakin diciutkan oleh faktor-faktor eksternal seperti memburuknya kondisi neraca pembayaran, meningkatnya masalah utang luar negeri dan kebijakan lainnya, yang pada gilirannya telah mengakibatkan kemerosotan pertumbuhan industri, tingkat upah, dan akhirnya, penyediaan lapangan kerja (Todaro, 2000).

Salah satu usaha yang dilakukan oleh pemerintah dalam mengatasi masalah ketenagakerjaan yaitu memperbaiki sistem upah melalui kebijakan upah minimum. Penerapan kebijakan upah minimum merupakan usaha dalam rangka meningkatkan upah pekerja sehingga tingkat upah rata-rata tenaga kerja dapat meningkat. Kebijakan upah minimum merupakan sistem pengupahan yang telah banyak diterapkan di beberapa negara, yang pada dasarnya bisa dilihat dari dua sisi. Pertama, upah minimum merupakan alat proteksi bagi pekerja untuk mempertahankan agar nilai upah yang diterima tidak menurun dalam memenuhi kebutuhan hidup sehari-hari. Kedua, sebagai alat proteksi bagi perusahaan untuk mempertahankan produktivitas pekerja (Simanjuntak, dalam Gianie, 2009:1). Beriku beberapa penelitian terdahulu tentang upah, yaitu: Gindling fan Terrell (2006), Rini (2013), Rizal Azaini (2014), dan Wasilaputri (2016). Hasil penelitian menyatakan bahwa upah minimum provinsi berpengaruh negatif terhadap penyerapan tenaga kerja.

Selain upah, ada beberapa faktor yang juga mendapat perhatian dari pemerintah sebagai upaya mengatasi permasalahan ketenagakerjaan yaitu Produk Domestik Regional Bruto (PDRB) dan Investasi. PDRB merupakan nilai tambah atas barang dan jasa yang dihasilkan oleh berbagai unit produksi atau sektor di suatu daerah dalam jangka waktu tertentu. PDRB dapat mempengaruhi jumlah angkatan kerja yang bekerja dengan asumsi apabila nilai PDRB meningkat, maka jumlah nilai tambah output atau penjualan dalam seluruh unit ekonomi disuatu wilayah akan meningkat. Meningkatnya output atau penjualan yang dilakukan perusahaan maka akan mendorong perusahaan untuk menambah permintaan tenaga kerjanya agar produksinya dapat ditingkatkan untuk mengejar peningkatan penjualan yang terjadi (Feriyanto, 2014). Atau dengan kata lain dinyatakan peningkatan PDRB akan meningkatkan permintaan tenaga kerja, ada hubungan positif antara PDRB dengan penyerapan tenaga kerja. 
Sektor industri di yakini sebagai sektor yang dapat memimpin sektor-sektor lain dalam sebuah perekonomian menuju kemajuan. Produk-produk industrial selalu memiliki "dasar tukar" (term of trade) yang tinggi atau lebih menguntungkan serta menciptakan nilai tambah yang besar dibanding produk-produk sektor lain. Sejalan dengan hal tersebut, maka peran sektor industri akan semakin penting sehingga dapat dijadikan sebagai prioritas pembangunan yang memiliki peranan sebagai sektor pemimpin bagi pembangunan sektor-sektor lainnya. Salah satu syarat utama bagi pembangunan ekonomi adalah kriteria investasi, dimana tujuan utama dari investasi adalah untuk memperoleh manfaat yang layak di kemudian hari, apabila kegiatan investasi meningkat, maka kegiatan ekonomi pun ikut meningkat. Dengan adanya investasi maka akan meningkatkan produksi dan berdampak pada tingkat penyerapan tenaga kerja.

Investasi merupakan pengeluaran pemerintah dan non pemerintah (swasta), dimana membutuhkan modal riil untuk mendirikan perusahaan baru dengan hasil keutungan mereka dan dapat memperluas usaha yang telah ada. Sehingga dampak positifnya adalah memberikan peningkatan penyerapan tenaga kerja dan peluang kerja bagi masyarakat. Selain itu pula dapat memperoleh keuntungan lebih besar dari modal awal dengan menginvestasikan modalnya tersebut. Investasi khususnya investasi yang berorientasi padat karya sehingga akan memperluas lapangan kerja, dari pada industri padat modal yang hanya menambah modal secara terus menerus tetapi tidak berdampak positif bagi penyerapan tenaga kerja.

\section{METODELOGI PENELITIAN}

\section{Jenis dan Sumber Data}

Penelitian ini menggunakan pendekatan deskriptif kuantitatif dan analisis data panel. Data yang digunakan adalah data panel enam Provinsi di Pulau Jawa Tahun 2010-2016. Data akan diolah menggunakan teknik data panel yang merupakan kombinasi dari data time series dan cross section. Data ini bersumber dari Badan Pusat Statistik (BPS) Pulau Jawa Dalam Angka. Adapun data yang diperlukan dalam penelitian ini adalah data Upah Minimum Provinsi (UMP), data Produk Domestik Regional Bruto (PDRB), dan Investasi. Data tersebut adalah investasi yang berasal dari Penanaman Modal Dalam Negeri (PMDN) dan Penanaman Modal Asing (PMA).

\section{Metode Analisis Data}

Analisis data yang digunakan dalam penelitian ini adalah estimasi data panel. Data panel yaitu model ekonometri yang menyatukan antara deret waktu (time series) dan data kerat lintang (cross section), model ini ditransformasi ke dalam bentuk model logaritma (Log), sebagai berikut:

\section{$\operatorname{LogPTKI}_{i t}=\log \beta_{0}+\beta_{1} \log U M P_{i t}+\beta_{2} \log P D R B_{i t}+\beta_{3} \log I_{i t}+e_{i t}$}

Keterangan :

$\begin{array}{ll}\text { Log } & \text { Logaritma } \\ \text { PTKI } & =\text { Penyerapan tenaga kerja industry (jiwa) } \\ \text { UMP } & =\text { Upah minimum provinsi (rupiah) } \\ \text { PDRB } & =\text { Produk domestik regional bruto sektor industri (miliar rupiah) }\end{array}$ 


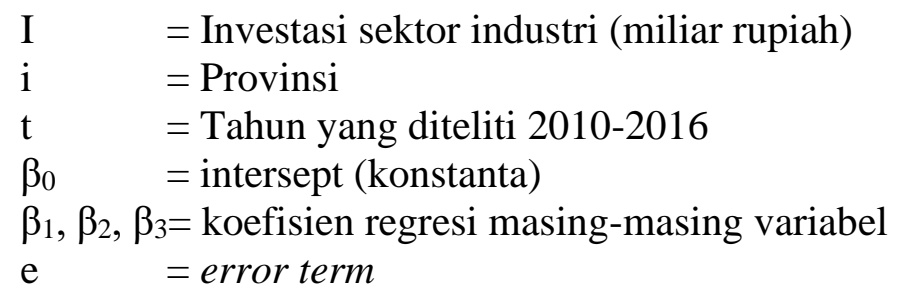

\section{Metode Estimasi Data Panel}

Data panel menurut Gujarati (2003) merupakan suatu data cross section (individu/sektor) yang disusun berdasarkan runtun waktu (time series). Terdapat tiga pendekatan dalam perhitungan model data panel, yaitu: Common Effect (PLS), Fixed Effect (FEM), dan Random Effect (REM). Tentu dalam pengujian diharuskan memilih permodelan yang terbaik. Maka terdapat dua cara pengujian yang umum digunakan yaitu uji Chow (pengujian yang dilakukan untuk memilih model pendekatan yang paling baik antara Common Effect dan Fixed Effect) dan uji Hausman (pengujian ini untuk memilih model terbaik anatara Fixed Effect atau Random Effect), serta Uji Breusch-Pagan (pengujian ini untuk memilih model terbaik anatara Common Effect atau Random Effect).

\section{Metode Pemilihan Model (Uji Kesesuaian Model)}

\section{Uji Chow}

Pengujian yang dilakukan untuk memilih apakah model akan dianalisis menggunakan common effect model (CEM) atau fixed effect model (FEM) dapat dilakukan dengan Uji Chow.

\section{Uji Hausman}

Pengujian untuk memilih apakah model akan dianalisis menggunakan random effect model (REM) atau fixed effect model (FEM) dapat dilakukan dengan uji hausman.

\section{Uji Langrange Multiple (LM)}

Pengujian untuk memilih apakah model akan dianalisis menggunakan metode random effect atau common effect. Uji Langrange Multiple (LM) didasarkan pada distribusi ChiSquares dengan derajat kebebasan (df) sebesar jumlah variabel independen.

\section{Uji Asumsi Klasik}

\section{Uji Normalitas}

Pengujian normalitas data adalah pengujian tentang kenormalan distribusi residual data. Pengujian normalitas dilakukan dengan maksud untuk melihat normal tidaknya residual yang dianalisis. Selain menggunakan grafik, uji normalitas juga dapat dilakukan dengan metode Jarque-Berra (uji $J B$ ) atau dengan melihat plot dari sisaan. Keputusan terdistribusi normal tidaknya residual secara sederhana dengan membandingkan nilai Probabilitas JB (Jarque-Bera) hitung dengan tingkat alpha 0,05 (5\%). Apabila Prob. JB hitung $>\alpha 0,05$ maka dapat disimpulkan bahwa residual terdistribusi normal. Sebaliknya jika Prob. JB hitung $<\alpha 0,05$ maka tidak cukup bukti untuk menyatakan bahwa residual terdistribusi normal.

\section{Multikolinieritas}

Salah satu cara untuk mendeteksi adanya multikolinearitas dengan melihat nilai koefisien korelasi antara peubah bebas dalam model. Jika nilai masing-masing koefisien 
korelasinya lebih besar dari rule of thumb (0.8) maka model tersebut mengandung multikolinearitas.

\section{Heteroskesdastisitas}

Uji ini bertujuan untuk menguji apakah dalam sebuah model regresi terjadi ketidaknyamanan varian dari residual satu pengamatan ke pengamatan lain. Jika varian berbeda, disebut heteroskedastisitas. Salah satu cara untuk mengetahui ada tidaknya heteroskedastisitas dalam suatu model regresi linier berganda adalah dengan melihat grafik sccatterplot atau nilai prediksi variabel terikat yaitu SRESID dengan residual error yaitu ZPRED. Jika tidak ada pola tertentu dan tidak menyebar diatas dan dibawah angka nol pada sumbu y, maka tidak terjadi heteroskedastisitas. Model yang baik adalah yang tidak terjadi heteroskedastisitas (Ghozali, 2016;134).

\section{Autokorelasi}

Menurut Ghozali $(2016 ; 107)$ autokorelasi muncul karena observasi yang berurutan sepanjang waktu berkaitan satu sama lainnya. Permasalahan ini muncul karena residual tidak bebas dari satu observasi ke observasi lainnya. Model regresi yang baik adalah model regresi yang bebas dari autokolerasi. Cara untuk mendeteksi ada tidaknya autokorelasi adalah dengan uji Run Test. Run test merupakan bagian dari statistik nonparametik dapat pula digunakan untuk menguji apakah antar residual terdapat korelasi yang tinggi. Jika antar residual tidak terdapat hubungan korelasi maka dikatakan bahwa residual adalah acak atau random. Run test digunakan untuk melihat apakah data residual terjadi secara random atau tidak (sistematis).

\section{Uji Hipotesis}

\section{Uji t-statistik}

Uji t-statistik digunakan untuk mengetahui pengaruh variabel independen secara parsial terhadap variabel dependen. Uji $\mathrm{t}$ dapat dilakukan dengan membandingkan nilai probability $\alpha=0,05 \%$ dengan taraf signifikansinya.

\section{Uji F Statistik}

Untuk menunjukkan apakah keseluruhan variabel bebas berpengaruh terhadap variabel terikat pada tingkat $\alpha=0,05 \%$.

\section{Uji Koefisien Determinasi $\left(\mathbf{R}^{2}\right)$}

Koefisien Determinasi $\left(\mathrm{R}^{2}\right)$ mengukur seberapa besar variabel independen dalam model dapat menjelaskan variabel dependen yang digunakan dalam penelitian.

\section{HASIL DAN PEMBAHASAN}

\section{Pengujian Model Data}

\section{Uji Chow}

Menurut Widarjono (2013), Uji Chow merupakan pengujian yang dilakukan untuk memilih model pendekatan yang paling baik antara Common Effect(CE) dan Fixed Effect(FE) dengan melihat nilai distribusi F statistik. 
Tabel 1. Uji Chow

Redundant Fixed Effects Tests

Equation: EQ01

Test cross-section fixed effects

\begin{tabular}{lccc}
\hline Effects Test & Statistic & d.f. & Prob. \\
\hline Cross-section F & 2260.678444 & $(5.33)$ & 0.0000 \\
\hline
\end{tabular}

Sumber: Output Eviews 8

Tabel 1 menunjukkan bahwa nilai Prob. Cross-section F sebesar 0,0000 lebih kecil dari taraf nyata $(\alpha) 5 \%,(0,0000<0,05)$ maka Ho tidak dapat diterima atau berarti metode Fixed Effect Model (FEM) lebih baik dari pada metode Common Effect Model (CEM) dalam menganalisis data panel di penelitian ini.

\section{Uji Hausman}

Uji Hausman merupakan pengujian yang dilakukan untuk membandingkan dan memilih antara Random Effect Model (REM) dan Fixed Effect Model (FEM).

\section{Tabel 2. Hasil Uji Hausman}

Correlated Random Effects - Hausman Test

Equation: EQ01

Test cross-section random effects

Test Summary Chi-Sq. Statistic Chi-Sq. d.f.

Prob.

Cross-section random $14.733620 \quad 3$

0.0021

Sumber: Output Eviews 8

Berdasarkan Tabel 2 diperoleh nilai Chi-Squares Statistic sebesar 14,733620 yanglebih besar dari nilai Chi-Squares tabel sebesar 7,81, maka $\mathrm{H}_{0}$ tidak dapat diterima atau berarti metode Fixed Effect (FEM) lebih baik dari pada metode Random Effect (REM) dalam menganalisis data panel di penelitian ini.

\section{Uji Breusch-Pagan LM}

Uji Breusch-Pagan Lagrange Multiplier (LM) dilakukan untuk memilih metode terbaik antara Common Effect Model (CEM) dengan Random Effect Model (REM).

Tabel 3. Hasil Uji Breusch-Pagan Lagrange Multiplier (LM)

\begin{tabular}{lccc}
\hline $\begin{array}{l}\text { Null (no rand. Effect) } \\
\text { Alternative }\end{array}$ & $\begin{array}{c}\text { Cross-section } \\
\text { One-sided }\end{array}$ & $\begin{array}{c}\text { Period } \\
\text { One-sided }\end{array}$ & Both \\
\hline Breusch-Pagan & 39.323363 & 0.327176 & 39.65053 \\
& $(0.0000)$ & $(0.5673)$ & $(0.0000)$ \\
\hline
\end{tabular}

Sumber: Output Eviews 8

Berdasarkan Tabel 3 diperoleh nilai Cross-section Breusch-Pagan adalah sebesar 39,32336 yang lebih besar dari nilai kritis Chi-Squares tabel sebesar 7,81, maka $\mathrm{H}_{0}$ tidak dapat diterima artinya metode Random Effect Model (REM) lebih baik dari pada metode Common Effect Model (CEM) untuk menganalisis data panel penelitian maka 
disimpulkan analisis diperlukan selanjutnya akan menggunakan model Random Effect (RE).

\section{Hasil Regresi Fixed Effect Model}

$$
\begin{aligned}
& \operatorname{LogPTKI}{ }_{i t}=8,399585-0,874935 \operatorname{LogUMP}_{i t}+0,561902 \operatorname{LogPDRB}_{\text {it }}+0,821413 \\
& \log I_{i t} \\
& \begin{array}{llll}
\text { s.e } & (0.030143) & (0.003497) & (0.003243)
\end{array}
\end{aligned}
$$

Keterangan : $\left.{ }^{* *}\right) \alpha=$ signifikan pada level 5\%

Berdasarkan hasil estimasi tersebut menunjukkan bahwa angka koefisien regresi variabel UMP adalah sebesar -0,874935. Hal ini menunjukkan bahwa terdapat pengaruh negatif $(\alpha=0,05)$ dari variabel UMP terhadap penyerapan tenaga kerja sektor industri di Pulau Jawa tahun 2010-2016. Setiap kenaikan UMP sebesar 1\%, akan cenderung menurunkan penyerapan tenaga kerja sektor industri di Pulau Jawa sebesar 0,87\%. Hasil penelitian yang telah dilakukan mendukung temuan dari Wasilaputri (2016) dalam penelitiannya menemukan bahwa tingkat upah memiliki pengaruh terhadap penyerapan tenaga kerja, dimana setiap kenaikan $1 \%$ upah minimum provinsi akan diikuti oleh penurunan penyerapan tenaga kerja sebesar $0,12 \%$, ceteris paribus.

Selanjutnya koefisien regresi variabel PDRB adalah sebesar 0,561902. Hal ini menunjukkan bahwa terdapat pengaruh positif $(\alpha=0,05)$ dari variabel PDRB terhadap penyerapan tenaga kerja sektor industri di Pulau Jawa tahun 2010-2016. Setiap kenaikan 1\% PDRB akan cenderung diikuti oleh kenaikan penyerapan tenaga kerja sebesar $0,56 \%$, ceteris paribus. Hal tersebut didukung oleh hasil penelitian yang dilakukan oleh Dimas dan Nenik (2009) yang menyatakan bahwa PDRB memiliki pengaruh yang positif terhadap penyerapan tenaga kerja di DKI Jakarta, apabila PDRB meningkat $1 \%$ maka penyerapan tenaga kerja meningkat sebesar $1,23 \%$.

Sedangkan koefisien regresi variabel investasi adalah sebesar 0,821413. Hal ini menunjukkan bahwa investasi berperngaruh positif $(\alpha=0,05)$ terhadap penyerapan tenaga kerja sektor industri di Pulau Jawa tahun 2012-2016. Setiap kenaikan investasi sebesar $1 \%$, akan cenderung menurunkan penyerapan tenaga kerja sektor industri di Pulau Jawa sebesar 0,82\%. Hal ini didukung oleh penelitian yang dilakukan Roni (2010), bahwa investasi berpengaruh positif dan signifikan terhadap penyerapan tenaga kerja di Indonesia. Ketika terjadi kenaikan investasi sebesar $1 \%$ maka akan meningkatkan penyerapan tenaga kerja sebesar $0,01 \%$.

\section{Tabel 4. Nilai Prediksi}

\begin{tabular}{lcccccccc}
\hline & & & & & \multicolumn{3}{c}{ Nilai Prediksi PTKI * } \\
\cline { 6 - 8 } Provinsi & \multicolumn{3}{c}{ Koefisien } & & RATA -RATA & \multicolumn{4}{c}{$(\%)$} \\
\cline { 6 - 9 } & UMP & PDRB & I & PTKI & & \\
& $(\%)$ & $(\%)$ & $(\%)$ & & UMP & PDRB & I \\
\hline DKI Jakarta & $-0,87$ & 0,56 & 0,82 & 549.115 & $-4,777$ & 3,075 & 4,503 \\
& & & & & - & & \\
Jawa Barat & $-0,87$ & 0,56 & 0,82 & 3.490 .401 & 30,366 & 19,546 & 28,621
\end{tabular}




\begin{tabular}{lccccccc} 
Jawa Tengah & $-0,87$ & 0,56 & 0,82 & 3.098 .789 & 26,959 & 17,353 & 25,410 \\
DI Yogyakarta & $-0,87$ & 0,56 & 0,82 & 486.226 & $-4,230$ & 2,723 & 3,987 \\
& & & & & - & & \\
Jawa Tengah & $-0,87$ & 0,56 & 0,82 & 2.653 .167 & 23,083 & 14,858 & 21,756 \\
& & & & & - & & \\
Banten & $-0,87$ & 0,56 & 0,82 & 1.154 .834 & 10,047 & 6,467 & 9,470 \\
\hline
\end{tabular}

Sumber: Excel, data diolah

Keterangan : * Proyeksi UMP, PDRB, dan I apabila terjadi kenaikan sebesar 1\% terhadap penyerapan tenaga kerja.

Dari Tabel 4 dapat dilihat bahwa sumber pengaruh terbesar dari peningkatan tenaga kerja dapat dilihat dari Investasi yang berada di Provinsi Jawa Barat yaitu sebesar $28,621 \%$. Sedangkan sumber terendah dari peningkatan tenaga kerja berada di Provinsi Jawa Barat berupa UMP sebesar -30,366\%.

\section{Hasil Uji Asumsi Klasik}

\section{Uji Normalitas}

Berdasarkan hasil regresi, diketahui bahwa nilai probability sebesar 0,673936. Nilai probability 0,637634 >0,05 maka data berdistribusi normal. Sehingga dapat disimpulkan bahwa asumsi berdistribusi normal dalam model terpenuhi.

\section{Uji Autokorelasi}

Tabel 5. Hasil Uji Autokorelasi

\begin{tabular}{lcll}
\hline R-squared & 0.999816 & Mean dependent var & 8869.964 \\
Adjusted R-squared & 0.999772 & S.D. dependent var & 19852.85 \\
S.E. of regression & 1.090111 & Sum squared resid & 39.21527 \\
F-statistic & 22439.14 & Durbin-Watson stat & 1.910139 \\
Prob(F-statistic) & 0.000000 & Mean dependent var & \\
\hline
\end{tabular}

Sumber: Output Eviews 8

Berdasarkan Tabel 5 di atas diketahui bahwa nilai Durbin Watson sebesar 1,910139. Karena nilai $\mathrm{du}(1,67)<\mathrm{d}(1,910139)<4-\mathrm{du}(2,33)$ maka model regresi tidak mengandung autokorelasi atau asumsi tidak terjadi autokorelasi terpenuhi.

\section{Uji Multikolinieritas}

Tabel 6. Hasil Uji Multikolinieritas

\begin{tabular}{cccc}
\hline & LOG(UMP) & LOG(PDRB) & LOG(I) \\
\hline LOG(UMP) & 1.000000 & 0.146122 & 0.359374 \\
LOG(PDRB) & 0.146122 & 1.000000 & 0.395702 \\
LOG(I) & 0.359374 & 0.395702 & 1.000000 \\
\hline
\end{tabular}

Sumber: Output Eviews 8

Dari Tabel 6 diketahui bahwa nilai korelasi antar variabel bebas lebih kecil dari 0,8 ( $\mathrm{r}<$ 0,8 ) yang berarti model tidak mengandung masalah multikolinieritas atau asumsi tidak terjadi multikolinieritas dalam model terpenuhi. 


\section{Uji Heteroskedastisitas}

Tabel 7. Hasil Uji Heteroskedastisitas

\begin{tabular}{ccccc}
\hline Variabel & Coefficient & Std. Error & t-Statistic & Prob. \\
\hline C & 7.316670 & 5.162388 & 1.417303 & 0.1658 \\
LOG(UMP) & -1.557550 & 2.223159 & -0.700602 & 0.4885 \\
LOG(PDRB) & -0.583479 & 0.421714 & -1.383588 & 0.1758 \\
LOG(I) & 1.576293 & 1.841920 & 0.855788 & 0.3983 \\
\hline
\end{tabular}

Sumber: Output Eviews 8

Berdasarkan Tabel 7 nilai probabilitas dari masing-masing variabel bebas tidak ada yang signifikan ( $p$-value $>0.05$ ).Hal ini menunjukkan bahwa model bersifat homoskedastis atau asumsi tidak mengandung heteroskedastis terpenuhi.

\section{Uji Hipotesis}

\section{Uji t-statistik (Keberartian Parsial)}

Tabel 8. Hasil Uji t-statistik

\begin{tabular}{lccccl}
\hline Variabel & Koefisien & t-statistik & t-tabel & Prob. & Kesimpulan \\
\hline UMP & -0.874935 & -250.1811 & -1.68595 & 0.0000 & TolakH \\
PDRB & 0.561902 & 173.2863 & 1.68595 & 0.0000 & Tolak $\mathrm{H}_{\mathrm{o}}$ \\
Investasi & 0.821413 & 261.7905 & 1.68595 & 0.0000 & Tolak $\mathrm{H}_{\mathrm{o}}$ \\
\hline
\end{tabular}

Sumber: Output Eviews 8

Berdasarkan Tabel 8 menunjukkan nilai t-statistik variabel sebesar $-250,1881$ sedangkan nilai t-tabel sebesar -1,68595. Hal ini menunjukkan bahwa nilai t-statistik lebih besar daripada nilai t-tabel. Dengan demikian H0 ditolak dan Ha diterima, artinya variabel UMP berpengaruh negatif dan signifikan terhadap penyerapan tenaga kerja. Variabel PDRB menunjukkan nilai t-statistik sebesar 173,2863 sedangkan nilai t-tabel sebesar 1,68595. Hal ini menunjukkan bahwa nilai t-statistik lebih besar daripada nilai t-tabel. Dengan demikian HO ditolak dan Ha diterima, artinya variabel PDRB berpengaruh positif dan signifikan terhadap penyerapan tenaga kerja di Pulau Jawa. Variabel Investasi menunjukkan nilai t-statistik variabel sebesar 261,7905 sedangkan nilai t-tabel sebesar 1,68595. Hal ini menunjukkan bahwa nilai t-statistik lebih besar daripada nilai t-tabel. Dengan demikian H0 ditolak dan Ha diterima, artinya variabel PDRBberpengaruh positifdan signifikan terhadap penyerapan tenaga kerja di Pulau Jawa.

\section{Uji F-statistik}

Tabel 9. Hasil Uji F-statistik

\begin{tabular}{lcccc}
\hline $\mathbf{D f}=(\mathbf{k}-\mathbf{1} ; \mathbf{n}-\mathbf{k})$ & $\boldsymbol{\alpha}$ & F-tabel & F-Statistik & Kesimpulan \\
\hline$(3 ; 39)$ & $5 \%$ & 2.85 & 22439.14 & Menolak $\mathrm{H}_{\mathrm{o}}$ \\
\hline
\end{tabular}

Sumber: Output Eviews 8

Tabel 9 menunjukkan bahwa nilai F-statistik sebesar 22439,14 dan nilai F-tabel sebesar 2,85. Nilai F-statistik ini lebih besar dibandingkan nilai F-tabel pada tingkat signifikansi 


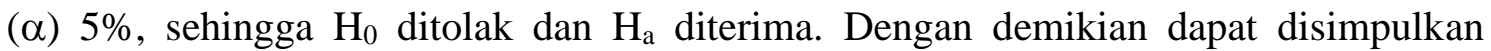
bahwa variabel UMP, PDRB, dan Investasisecara bersama-sama berpengaruh terhadappenyerapan tenaga kerja sektor industri di Pulau Jawa.

\section{KESIMPULAN DAN SARAN}

\section{Kesimpulan}

Berdasarkan hasil pengolahan data dan pembahasan yang telah dilakukan, maka dapat disimpulkan bahwa Upah Minimum Provinsi (UMP) berpengaruh negatif dan signifikan terhadap penyerapan tenga kerja sektor industri di Pulau Jawa tahun 2010-2016. Sedangkan PDRB dan Investasi berpengaruh positif dan signifikan terhadap penyerapan tenga kerja sektor industri di Pulau Jawa tahun 2010-2016.

\section{Saran}

Pemerintah harus berhati-hati dalam menaikkan UMP karena akan memunculkan penurunan penyerapan tenaga kerja. Berdasarkan hasil estimasi terlihat seperti itu, ada penurunan setiap persen dari setiap kenaikkan $1 \%$ dari UMP. Ke depannya harus berhati-hati, jika ingin menciptakan lapangan kerja baru. Selain itu investasi mempengaruhi penyerapan tenaga kerja, maka diharapkan Pemerintah untuk lebih menciptakan iklim investasi yang kondusif, seperti dengan melakukan promosi investasi ke luar daerah, dan mempermudah perijinan investasi, sehingga nilai PDRB di Pulau Jawa lebih meningkat.

\section{REFERENSI}

Adil. 2017. Analisis Faktor-Faktor Yang Mempengaruhi Penyerapan Tenaga Kerja Pada Sektor Industri Pengolahan di Provinsi Sulawesi Selatan Periode 20062015. Universitas Islam Negeri Alauddin Makassar.

Afrizal, Fitrah. 2013. AnalisisPengaruhInvestasi, BelanjaPemerintah Dan DanTenagaKerjaTerhadap PDRB DI Sulawesi Selatan 2001-2011. Makassar UniversitasHasanuddin.Skripsi(Tidakdipublikasikan).

Akmal, Roni. 2010. Analisis Faktor-faktor yang Mempengaruhi Penyerapan Tenaga Kerja di Indonesia. Skripsi. Fakultas Ekonomi Universitas Andalas. Sumatra Barat.

Chusna, A. 2013. Pengaruh Laju Pertumbuhan Sektor Industri, Investasi, dan Upah terhadap Penyerapan Tenaga Kerja Sektor Industri di Provinsi Jawa Tengah Tahun1980-2011. Journal of Economics Development. Universitas Negeri Semarang.

Dimas dan Woyanti, N. 2009. Penyerapan Tenaga Kerja di DKI Jakarta. Jurnal. Fakultas Ekonomi Universitas Diponegoro, Semarang.

Gianie. 2009. Pengaruh Upah Minimum Terhadap Penyerapan Tenaga Kerja Berpendidikan Rendah. Tesis. Fakultas Ekonomi Universitas Indonesia.

Gindling T.H and Terrel Katherine. 2006. The Effect of Multiple Minimum Wage Throughout the Labour Market: The Case os Costa Rica. Journal of Labour Economics. 14 (2007) Hal. 485-511

Gujarati, D.N., 2003. Basic Econometrics, McGraw-Hill. New York

Prihartanti, ED. 2007. Analisis Faktor-faktor yang Mempengaruhi Penyerapan Tenaga Kerja Sektor Industri di Kota Bogor [skripsi]. Fakultas Ekonomi dan Manajemen, Institut Pertanian Bogor. 